\title{
Mimosa scabrella Benth. planted for forest restoration in southern Brazil
}

\author{
Mimosa scabrella Benth. plantada para restauração florestal no sull do Brasil \\ Mimosa scabrella Benth. plantada para la restauración forestal en el sur de Brasil
}

Received: 02/03/2021 | Reviewed: 02/12/2021 | Accept: 03/10/2021 | Published: 03/18/2021

Dionatan Gerber
ORCID: https://orcid.org/0000-0002-0544-1679
Instituto Politécnico de Bragança, Portugal
E-mail: dionatan_gerber@ hotmail.com
Larissa Regina Topanotti
ORCID: https://orcid.org/0000-0001-5066-4196
Universidade Federal de Santa Catarina, Brazil
E-mail: larissa.topanotti@ufsc.br
Oiliam Carlos Stolarski
ORCID: https://orcid.org/0000-0003-4119-2654
Casa da Floresta, Brazil
E-mail: oiliam_stolarski@ @otmail.com
Bruna Elisa Trentin
ORCID: https://orcid.org/0000-0003-1823-6030
Universidade Tecnológica Federal do Paraná, Brazil
E-mail: brunaelisatrentin@ @mail.com
Marcos Felipe Nicoletti
ORCID: https://orcid.org/0000-0003-4732-0119
Universidade do Estado de Santa Catarina, Brazil
E-mail: marcos.nicoletti @udesc.br
Fernando Campanhã Bechara

\begin{abstract}
Tropical trees planting resurgent in a global warming scenario, and this activity relies on information about forest species ecology and its different functional traits. we evaluated the initial performance of Mimosa scabrella using the Generalized Linear Models (GLM) technique to fit mathematical models for collar diameter growth $\mathrm{x}$ height, and for crown projection area $\mathrm{x}$ collar diameter in a forest restoration planting. The following variables were obtained in the first four years after planting: collar diameter $(\mathrm{mm})$, total height $(\mathrm{m})$, crown projection area $\left(\mathrm{m}^{2}\right)$ and crown volume $\left(\mathrm{m}^{3}\right)$. The models fitting was performed by GLM on Gamma, Normal and Poisson distribution, identity and logarithmical join function, and they were analyzed based on Akaike and Bayesian Information Criteria, standard deviation of the estimate and determination coefficient. M. scabrella showed an excelled performance on the 48 months of age, with average increment of $200.28 \mathrm{~mm}$ in collar diameter, $6.88 \mathrm{~m}$ in total height, $2.95 \mathrm{~m}^{2}$ in $\mathrm{crown}$ projection area and $83.41 \mathrm{~m}^{3}$ in crown volume. Its growth reduced only on periods of frost occurrence, but it restarted after these climatic events. The species growth, as well as its high survival rates and resprouting, allow its recommendation as a shady species of fast canopy fulfillment in forest restoration projects.
\end{abstract}

Keywords: Silviculture; Canopy formation; Reforestation.

\section{Resumo}

O plantio de árvores tropicais ressurge em um cenário de aquecimento global, e esta atividade se baseia em informações sobre a ecologia das espécies florestais e suas qualidades funcionais. O objetivo deste trabalho foi avaliar o desenvolvimento inicial de Mimosa scabrella utilizando-se da técnica dos Modelos Lineares Generalizados (MLG) para ajustar modelos matemáticos de crescimento em diâmetro colo em função da co-variável altura, e para a área de projeção de copa em função do diâmetro do colo em plantio de restauração florestal. Nos primeiros 4 anos após o plantio, foram obtidas as seguintes variáveis: diâmetro do colo $(\mathrm{mm})$, altura total $(\mathrm{m})$, área de projeção de copa $\left(\mathrm{m}^{2}\right)$ e volume de copa $\left(\mathrm{m}^{3}\right)$. O ajuste dos modelos foi realizado pelos modelos lineares generalizados (MLG) nos campos de distribuição Gama, Normal e Poisson, função de ligação identidade e logarítmica, e analisados com base nos valores do Critério de Informação de Akaike, Critério de Informação Baysiano, erro padrão da estimativa e coeficiente de determinação. $M$. scabrella apresentou excelente desempenho aos 48 meses de idade com incremento médio em diâmetro de colo $(200,28 \mathrm{~mm})$, altura total $(6,88 \mathrm{~m})$, área de projeção de copa $\left(22,95 \mathrm{~m}^{2}\right)$ e volume de copa $(83,41$ $\mathrm{m}^{3}$ ), reduzindo seu crescimento somente nos períodos de ocorrência de geadas severas na região, porém retomando-o 
após os eventos. O crescimento da espécie associada à sua alta taxa de sobrevivência e rebrotação, confere a sua recomendação como espécie sombreadora de rápido preenchimento de dossel em projetos de reflorestamento.

Palavras-chave: Silvicultura; Formação de dossel; Reflorestamento.

\section{Resumen}

La plantación de árboles tropicales resurge en un escenario de calentamiento global, y esta actividad se basa en información sobre la ecología de las especies forestales y sus cualidades funcionales. El objetivo de este trabajo fue evaluar el desarrollo inicial de Mimosa scabrella mediante la técnica de Modelos Lineales Generalizados (MLG) para ajustar los modelos matemáticos de crecimiento en el diámetro del cuello en función de la variable de altura, y para el área de proyección del dosel en función del diámetro del cuello en una plantación de restauración forestal. En los primeros 4 años después de la plantación, fueron obtenidos las siguientes variables: diámetro del cuello (mm), altura total $(\mathrm{m})$, área de proyección del dosel $\left(\mathrm{m}^{2}\right)$ y volumen del dosel $\left(\mathrm{m}^{3}\right)$. Los modelos se ajustaron mediante modelos lineales generalizados (MLG) en los campos de distribución Gamma, Normal y Poisson, identidad y función de enlace logarítmico, y analizados en base a los valores del Criterio de información de Akaike, Criterio de información Baysiano, error estándar de estimación y coeficiente de determinación. M. scabrella mostró un excelente desempeño a los 48 meses de edad con incremento medio en diámetro del cuello $(200,28 \mathrm{~mm})$, altura total $(6,88 \mathrm{~m})$, área de proyección del dosel $\left(22,95 \mathrm{~m}^{2}\right)$ y volumen del toldo $\left(83,41 \mathrm{~m}^{3}\right)$, reduciendo su crecimiento solo durante los períodos de fuertes heladas en la región, pero retomándolo después de los eventos. El crecimiento de la especie asociado a su alta tasa de supervivencia y rebrote, da su recomendación como una especie de sombra de rápido crecimiento del dosel en proyectos de reforestación.

Palabras clave: Silvicultura; Formación de dosel; Reforestación.

\section{Introduction}

Biodiversity conservation of forest ecosystems has been one of the main concerns of humanity in the last decades (Benayas et al., 2009). Tropical trees planting has arisen in a global warming scenario (Ripple et al., 2020), and this activity relies on information about forest species ecologic suitability in their different functional traits. The use of mathematical modeling is an important tool for monitoring the growth rate of tropical tree species, which is becoming increasingly important.

Mimosa scabrella Benth., popularly known in Brazil as "bracatinga", belongs to the Fabaceae family, Mimosoideae subfamily, and it is a native and endemic Brazilian species. It shows broad geographic distribution, occurring especially in southern Brazil, but also in parts of Minas Gerais, Rio de Janeiro and São Paulo states (Dutra \& Morim, 2017). It is a pioneer species and occurs, mainly, on natural or anthropic openings of secondary formations in the Araucaria Forest, in high abundance, gradually replacing herb and shrub species of initial successional stages. Its distribution comprises altitudes from 300 to $1,800 \mathrm{~m}$ (Klein, 1981; Carvalho, 1994, 2002). This species stands out by its fast growth, reaching up to $20 \mathrm{~m}$ in height and $40 \mathrm{~cm}$ in dbh (Reitz, Klein \& Reis, 1978; Fabrowski et al., 2005). It can reach its reproductive age at three years and live up to 30 years (Machado et al., 2006).

M. scabrella is perennial, low demanding in terms of physical and chemical soil conditions, and, due to is fast growth, is indicated for the reforestation of degraded areas (Carvalho, 1994). The species rusticity and light-demanding characteristics provides fast area coverage in a wide range of soils, such as riverbanks, forest edges and also degraded soils. Furthermore, characteristics as high increment rates, short-life and strong interaction with soil micro-organisms (nitrogen fixing bacteria and mycorrhizae), insects (mealy bugs, ants, bees, sawdust beetles) and vertebrates (birds and rodents) makes this species one of the main species indicated for facilitation in environment restoration programs (Reis \& Kageyama, 2003).

Besides its application in restoration projects, M. scabrella is also known by its vast potential for wood supply for the construction industry, sticks for vegetables cultivation, lumber, wood panels, pulp, and also as a bee-keeping, fodder and ornamental plant (Machado et al., 2006). We assessed the initial growth of M. scabrella in the Iguazu River basin, Paraná state, Brazil, up to 4 years old in a forest restoration plantation, using Generalized Linear Models (GLM) to fit mathematical models. 


\section{Methodology}

This study was carried out in an area of 7.2 ha at the Federal University of Technology - Parana, municipality of Dois

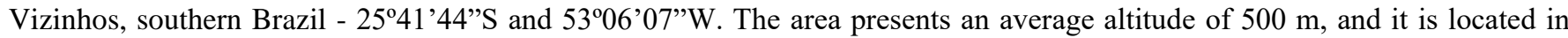
Araucaria Forest influenced by Seasonal Semideciduous Forest. The region in inserted in the third plateau of Paraná, with geological material from basaltic origin and soil characterized as Nitisol. The climate is described as Cfa subtropical (Alvares, Sentelhas \& Stape, 2018), with occurrence of frosts at least each two years, absence of dry season and average of $22^{\circ} \mathrm{C}$ in the warmest month.

In December 2010, 70 native tree species were planted (3 x $2 \mathrm{~m}$ spacing), in four plots of 54 x $40 \mathrm{~m}$ (Figure 1). In each plot, 18 seedlings of M. scabrella, from 30 to $60 \mathrm{~cm}$ high, were planted, totaling 72 plants. The seedlings were fertilized (5-20-10) into the holes, but also received $40 \mathrm{~g}$ of annual cover fertilization with urea, watered with hydrogel, and protected by cardboard mulching. Semesterly, weeds were controlled by mowing followed by glyphosate spraying. These silvicultural practices were done up to the third year.

Figure 1. Experimental plots sampled (black rectangles). Paraná, Brazil.

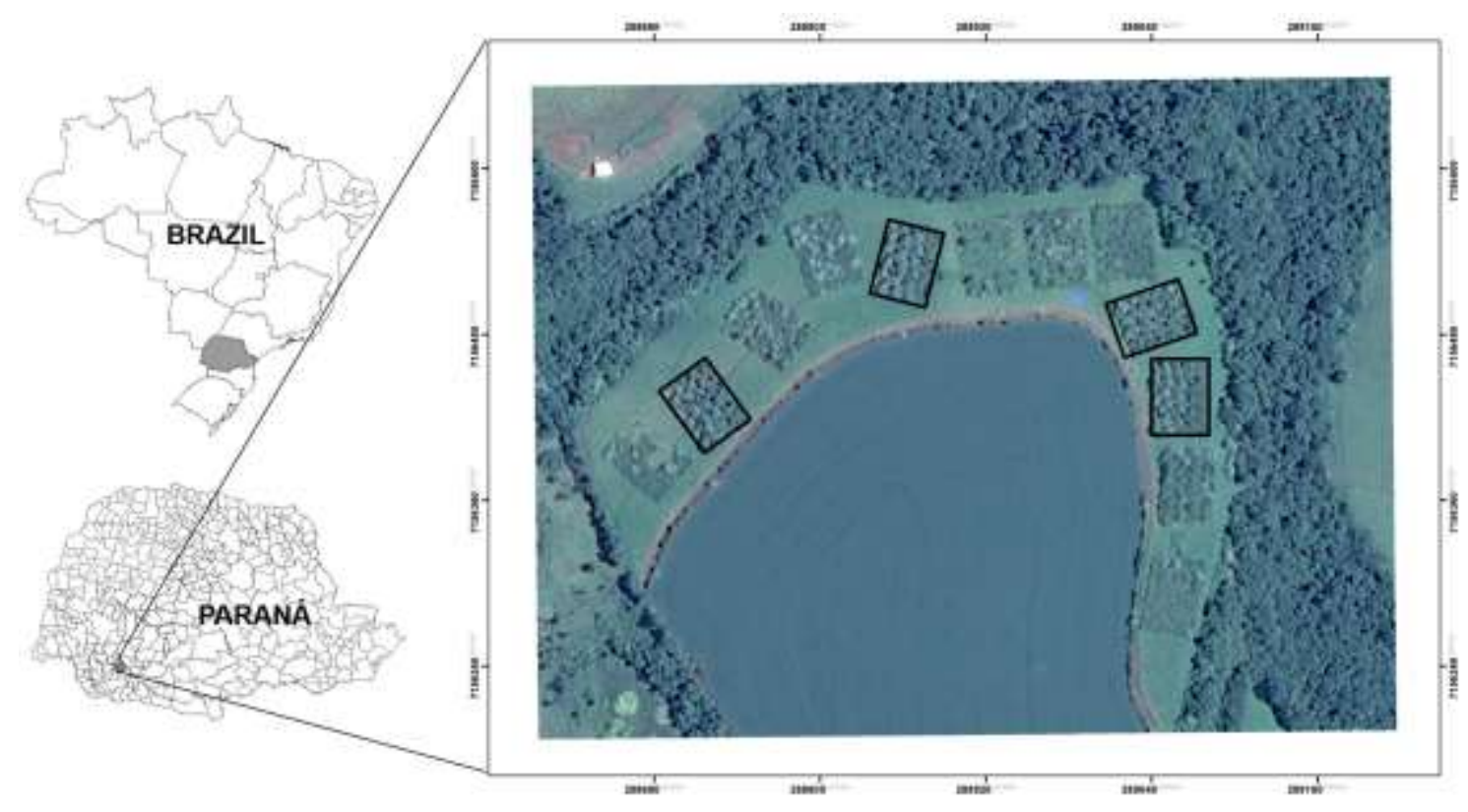

Source: Authors.

The data were collected biannually, measuring the following variables: survival $(\%)$, total height $(h-\mathrm{m})$, collar diameter $(c d-c m)$, crown projection area $\left(c a-\mathrm{m}^{2}\right)$, crown height $(c h-\mathrm{m})$ and crown volume $\left(c v-\mathrm{m}^{3}\right)$. Two measurements of the crown diameter were obtained, perpendicularly, which were used to calculate the crown projection area through the ellipse formula: $c a\left(\mathrm{~m}^{2}\right)=d l . d e . \pi / 4$, where $c a$ is the crown projection area; $d l$ and $d e$ are the crown diameters (m). The crown volume was estimated as an elliptical cylinder, multiplying the crown area by its length, as following: $c v\left(m^{3}\right)=c a . c h$, where $c v$ is the crown volume, $c a$ is the crown area $\left(\mathrm{m}^{2}\right)$, and $c h$ is the crown height $(\mathrm{m})$. According to Terborch and Petren (1991), this method underestimates the real crown volume, but presents an estimate of branches and leaves quantity existing on the forest canopy (Montgomery \& Chazdon, 2001).

To compare the species growth with temperatures and rainfall recorded during the observation window considered in this study, we used data from the meteorological station at the Federal University of Technology - Parana, Dois Vizinhos. 
Regarding to the mathematical model fitting for the initial growth in collar diameter in terms of total height and crown projection area in terms of total height, the Generalized Linear Models (GLM) were applied. The GLM were tested in the three random fields, Normal, Gama and Poisson, using the identity $(\mu)$ and ln logarithmic $(\mu)$ join functions. The model was defined by the following formula: $y=\beta_{0}+\beta_{1} \cdot x_{i}+\varepsilon$, where $y$ represents the variable characteristics (collar diameter and crown area) $x_{i}$ the trees number, $\beta_{0}$ and $\beta_{1}$ are the estimated coefficients, and $\varepsilon$ is the residual error. The fitting quality of the GLM models was assessed in terms of Akaike Information Criterion (AIC) and Bayesian Information Criterion (BIC), and the best model was the one with smaller value in both criteria (AIC and BIC). The models fitting was conducted on SAS V. 9.3. Statistical Software (SAS Institute Inc., 2004).

\section{Results and Discussion}

According to the meteorological data (Figure 2), frosts occurred during the 2011 and 2013 winters. The 2011 frosts occurred in June, July and August, with minimal temperatures under $3^{\circ} \mathrm{C}$, and the 2013 frosts took place in July and August, with minimal temperatures of -2.4 and $-1.8{ }^{\circ} \mathrm{C}$, respectively. Moreover, the annual water balance (Figure 3) showed an annual hydric deficit of $1.4 \mathrm{~mm}$ and $0.8 \mathrm{~mm}$ in August 2012 and February 2014, respectively (Gerber et al., 2020).

Figure 2. Monthly average temperatures $\left({ }^{\circ} \mathrm{C}\right)$ and absolute minimum temperature $\left({ }^{\circ} \mathrm{C}\right)$ registered on the study area from December 2010 to October 2014. Dois Vizinhos, Paraná, Brazil.

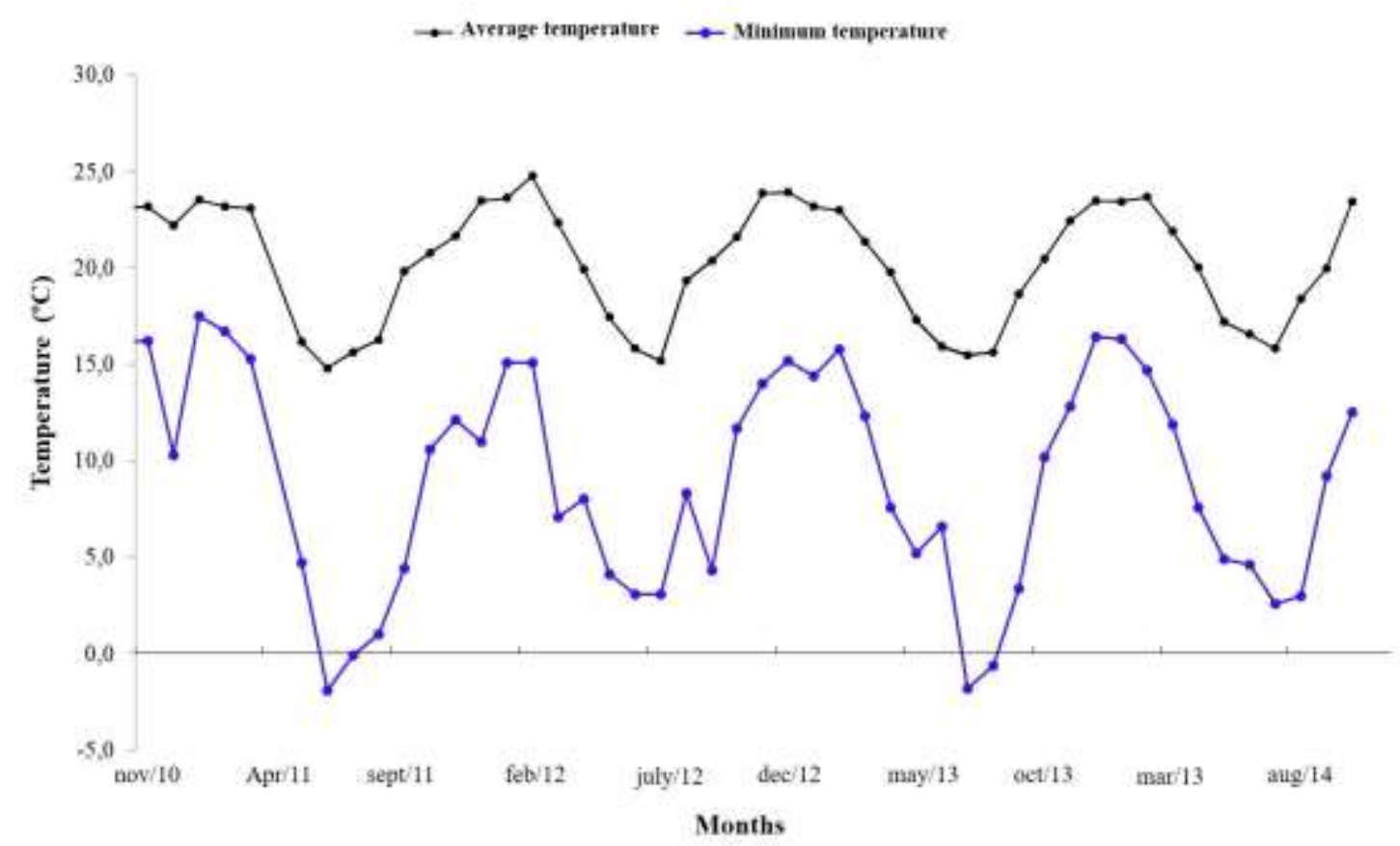

Source: Authors. 
Figure 3. Average monthly rainfall $(\mathrm{mm})$ registered on the study area from December 2010 to October 2014. Dois Vizinhos, Paraná, Brazil.

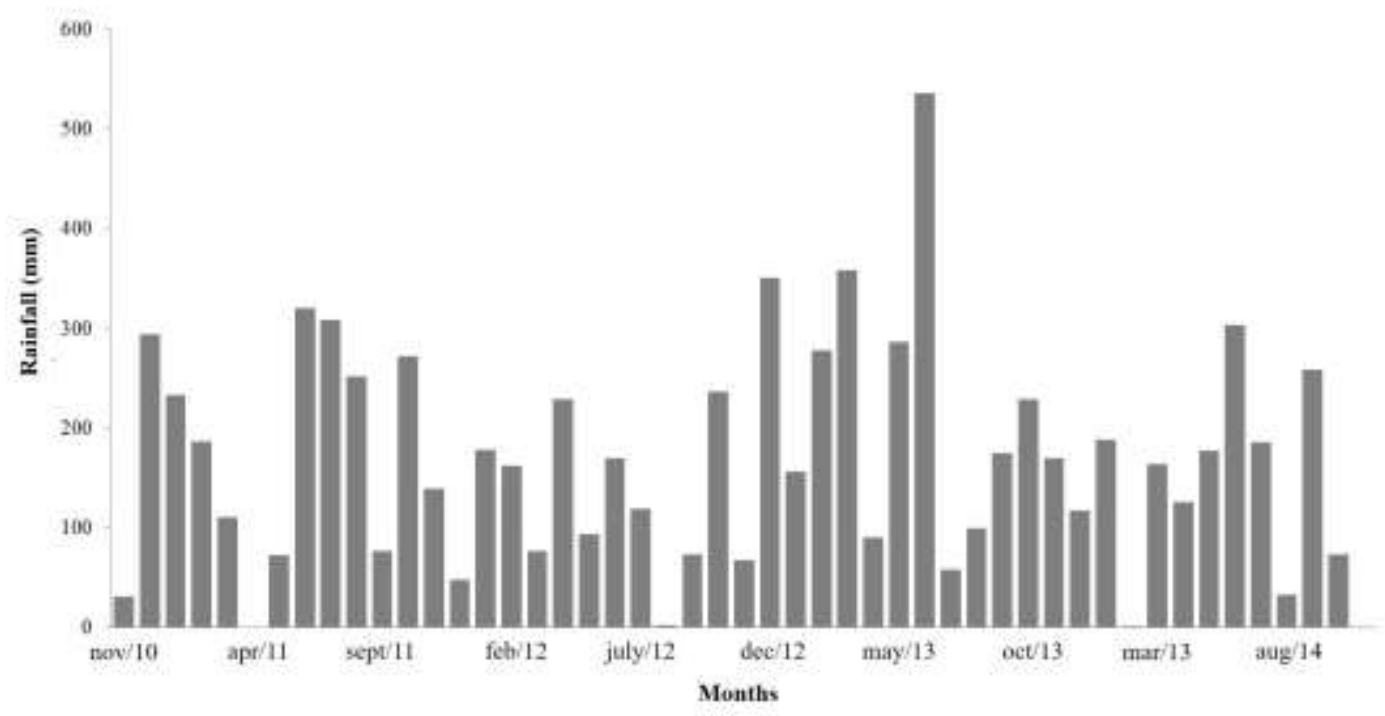

Source: Authors.

Carvalho (1982), studying the silvicultural performance of native forest species in a subtropical forest in South Brazil, proposed adequate levels of survival at 84 months of age, as follows: high ( $\geq 70 \%)$, regular $(\geq 50 \% \leq 69 \%)$ and low $(\leq 49 \%)$. Our survival rate for M. scabrella (89\%), was classified as high, showing that the species was tolerant to possible biotic and abiotic stresses.

M. scabrella presented a prominent silvicultural performance at 48 months. The lowest mean values for total height, collar diameter, crown projection area and crown volume were observed at 12 and 36 months. The decrease on mean height increment at 36 months was probably a result of the frosts during the winter, but at 42 months, the species increased significantly its silvicultural performance on this variable (Figure 4B). 
Figure 4. Boxplot of collar diameter (A), total height (B), crown projection area (C) and crown volume (D) of Mimosa scabrella assessed along 48 months. Dois Vizinhos, Paraná, Brazil.
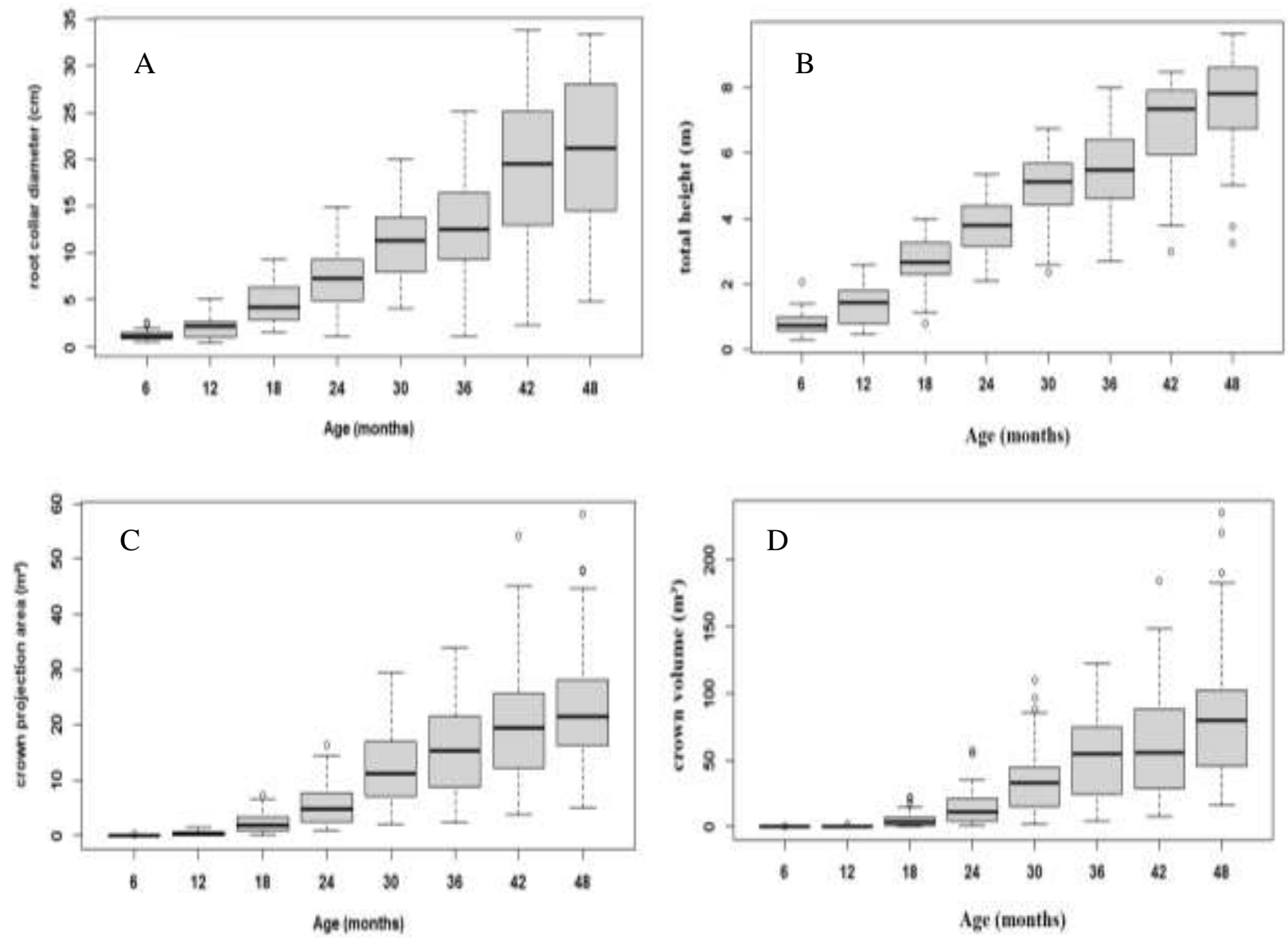

Source: Authors.

At the period of 36 months, frosts probably damaged the apical branches of some individuals, causing the decline on height (Figure 4B). As the individuals lost their apical dominance, the vegetative growth reduced in terms of height leading to the development of more than one lateral resprout. It demonstrates that the species is not properly called resistant, but, in fact, it is resilient to frosts due to its resprouting potential. The release of new sprouts after frost modified the species silvicultural behavior, which began to shade a bigger area. This fact indicates that these resprouts can be beneficial since the capacity of cover and shade the soil is an extremely important characteristic and it must be considered when choosing native tree species that promote forest succession (Wishnie et al., 2007).

At 48 months of age, the highest values in all variables were noticed, suggesting that, after 36 months of age, trees of M. scabrella can be considered as already recruited, even with low increment on height, crown projection area and crown volume provoked by the intense frosts. The mean individual crown volume was $83.44 \mathrm{~m}^{3}$ (Figure 4D). The mean crown projection area observed in this period was $23.01 \mathrm{~m}^{2}$ (Figure $4 \mathrm{C}$ ), three times bigger than the planting spacing, which was $6 \mathrm{~m}^{2}$, indicating a high efficiency on invasive grasses control, and an important feature for catalyzing the establishment of new species on the understory (Elliott, Blakesley, Hardwick, 2013, Chazdon, 2015).

The crown projection area and volume increased gradually over time (Figure 4B and 4D). However, the boxplots at 36 months showed a reduction on growth caused probably by the climate, which resulted in a median lower than the other periods. The physiological damage caused by the cold, from May to September, probably reduced the vegetative growth. 
On 2012, after the first severe winter, there was no evidence of frost occurrence in the region, so the trees developed normally. On 2013, however, frosts occurred again, consequently reducing the growth in collar diameter, crown projection area and crown volume at 36 months. Even susceptible to frosts, the M. scabrella individuals could overcome competition and occupied the forest canopy at 42 months of age.

In terms of the GLM models fitting, performance on AIC and BIC criteria are described on Table 1. The different models fitted on different ages can considerably explain the collar diameter variation at 48 months of age. However, the information criteria (standard deviation - s, AIC and BIC) showed different values due to the data heterogeneity, that varied in accordance with the fitted model chosen and the join function.

The fitted functions for crown projection area are associated with high values of AIC and BIC, which varied, respectively, between -0.5877 to 438.5171 and -3.1916 to 444.9937 (Table 1), and -1.4877 to 481.6205 and 4.1877 to 488.0972 (Table 2). The AIC and BIC define the fitting precision, as the lower the better. Its high values might be a result of the data heterogeneity that affected directly the functions fitting adjustment for different ages.

Table 1. Statistical parameters of the generalized linear model (GLM) to estimate collar diameter in terms of height for Mimosa scabrella in different ages. Dois Vizinhos, Paraná, Brazil.

\begin{tabular}{cccccccc}
\hline \multirow{2}{*}{ Months } & \multirow{2}{*}{ GLM } & \multirow{2}{*}{$\mathbf{F}$} & \multicolumn{2}{c}{ Estimated parameters } & \multicolumn{3}{c}{ Fitting criteria } \\
\cline { 5 - 8 } & & & $\boldsymbol{\beta 0}$ & $\boldsymbol{\beta 1}$ & $\mathbf{S}$ & AIC & BIC \\
\hline 6 & Normal & $\ln (\mu)$ & -0.9262 & 0.5984 & 1.4829 & -8.0243 & -3.1916 \\
12 & Gamma & $(\mu)$ & 0.3375 & 0.5021 & 1.7098 & -0.5877 & 5.0877 \\
18 & Normal & $(\mu)$ & 1.4101 & 0.2801 & 10.4098 & 71.2546 & 77.5872 \\
24 & Normal & $(\mu)$ & 2.0539 & 0.2270 & 15.2932 & 93.2809 & 99.4623 \\
30 & Poisson & $(\mu)$ & -0.6185 & 2.3107 & 47.5969 & 302.5452 & 306.7339 \\
36 & Normal & $(\mu)$ & 3.7897 & 0.1177 & 69.4857 & 185.0792 & 191.3623 \\
42 & Normal & $\ln (\mu)$ & 1.7479 & 0.1706 & 3236.5916 & 436.7127 & 443.1894 \\
48 & Normal & $\ln (\mu)$ & 2.1860 & 0.1123 & 3226.2811 & 438.5171 & 444.9937 \\
\hline
\end{tabular}

Where: GLM = Generalized Linear Model; JF = join function; $\mu=$ identity; $\mathrm{s}=$ standard deviation; BIC = Bayesian Information Criterion; $\mathrm{AIC}=$ Akaike Information Criterion. Source: Authors.

The allometric relation between collar diameter and height was discontinuous on different ages. Changes on growth pattern might be linked to frost occurrence, which reduced the development and resulted on death of the apical sprouts in some M. scabrella individuals, inducing lateral sprouting. These results agree with the hypothesis that individuals of the same species may present different allometric relation over their guilds (Guerin \& Mendonça, 2009).

It is possible to affirm that on 6 months of age M. scabrella focused on height growth. A continuous growth was observed from 12 months on, and it decreased at 36 months when there was a balance between height and collar diameter (Figure 3A and 3B). It probably indicates that this species tends to invest more in height growth than diameter. According to its allometric behavior, it can be noted that M. scabrella focus on height growth on the first years.

The investment on diameter is possibly related to the trunk capacity of sustaining the plant structure, resisting to its own mass and to the windthrow (Fontes, 1999, Sterck \& Bongers, 1998), which is intensified in opened degraded areas, edges and forest corridors (Santos et al., 2012). Thus, the collar diameter increase is directly associated with tree size since a tall tree with large crown has a significant mass as well, which requires a large diameter to stand its structure. This means that the increase in diameter in a plant occurs as it grows (Guerin \& Mendonça, 2009) demanding more support (Sterck \& Borges, 
1998). However, when the individuals reach a bigger size, the height proportion for a certain circumference tends to stabilize, so growth becomes continuous in both dimensions (Fontes, 1999).

The fitting criteria used to select the best fitting on different ages between crown projection area and total height are displayed on Table 2. Height could describe most of the crown area variation over time, but, again, the fitting criteria showed large variation due to the data heterogeneity.

Table 2. Statistical parameters of the Generalized Linear Model (GLM) to estimate crown projection area in terms of total height for Mimosa scabrella in different ages. Dois Vizinhos, Paraná, Brazil.

\begin{tabular}{cccccccc}
\hline \multirow{2}{*}{ Months } & \multirow{2}{*}{ GLM } & FL & \multicolumn{2}{c}{ Estimated parameters } & \multicolumn{3}{c}{ Fitting criteria } \\
\cline { 4 - 8 } & & & $\boldsymbol{\beta}$ & $\boldsymbol{\beta 1}$ & S & AIC & BIC \\
\hline 6 & Poisson & $(\mu)$ & -0.0460 & 0.1235 & 0.6846 & 23.6411 & 26.8629 \\
12 & Normal & $\ln (\mu)$ & -2.4404 & 1.0780 & 2.4624 & -1.4877 & 4.1877 \\
18 & Poisson & $(\mu)$ & -1.4125 & 1.1687 & 0 & 4.0000 & 8.2217 \\
24 & Gamma & $\ln (\mu)$ & -0.8782 & 0.6540 & 8.7480 & 236.3797 & 242.5610 \\
30 & Gamma & $(\mu)$ & -5.4848 & 3.4879 & 14.4452 & 369.4202 & 375.7032 \\
36 & Gamma & $\ln (\mu)$ & 1.3200 & 0.2577 & 13.2299 & 398.5507 & 404.8337 \\
42 & Gamma & $(\mu)$ & 3.7359 & 0.8595 & 6.8678 & 413.2580 & 419.7346 \\
48 & Gamma & $\ln (\mu)$ & 2.1825 & 0.1246 & 14.9062 & 481.6205 & 488.0972 \\
\hline
\end{tabular}

Where: GLM = Generalized Linear Model; JF = join function; $\mu=$ identity; $\mathrm{s}=$ standard deviation; BIC = Bayesian Information Criterion; $\mathrm{AIC}=$ Akaike Information Criterion. Source: Authors.

M. scabrella showed higher development in height at 12 months with lower investment rates in crown area. There was a constant increase in crown area investment on the following months, and it reached the asymptote at 30 months. After that, crown area reduced, keeping the allometric relation between crown area and height on constant levels of growth.

The species had a larger rise on height up to 30 months of age compared to the other months. This behavior could be typical of the species since it attempts to assure itself on the canopy during vegetation development (Fontes, 1999) or could be associated to ecological factors that have influenced the growth strategy change (Portela \& Santos, 2003). After its growth in height, this species starts to invest on crown area growth due to more light availability from less tree density, allowing the existence of lower live branches (Siqueira, 2006) and horizontal occupation (Costa et al., 2012). On the other hand, the canopy structuring increased crowns competition for light, favoring upper branches (Siqueira, 2006), and requiring a growth strategy on height. Another hypothesis is related to the development level of some individuals, which would already have crowns as mature individuals, so the increase in crown area in the following years would be smaller.

Santos et al. (2012) stated that different behavior presented by species in forests can be explained by their regeneration guilds and the strategies adopted to obtain the necessary resources for their development. Siqueira (2006) affirmed that the fitting to different allometric models by tree individuals for each environment suggests that ecological factors can play a restrictive role on species allometry. Therefore, the registered variations on allometry might be a result of the species specificity that can be driven by natural seasonal or sporadic events, requiring prompt reactions to outline a strate gy. This is a consensus decision in populations that have the same role in the ecosystem and occupy the same ecological niche. 


\section{Conclusion}

M. scabrella showed an excellent performance for reforestation, reducing its growth only when severe frosts occurred in the region and recovering it after such events. The species growth at 48 months of age, as well as its survival rate and resprouting, makes this species suitable for restoration projects, specially in South Brazil, as a shady species with fast canopy recovering ability.

\section{References}

Alvares, C. A., Sentelhas, P. C., \& Stape, J. L. (2018). Modeling monthly meteorological and agronomic frost days, based on minimum air temperature, in Center-Southern Brazil. Theoretical and Applied Climatology, 134(1), 177-191.

Benayas, J. M. R., Newton, A. C., Diaz, A. \& Bullock, J. M. (2009). Enhancement of biodiversity and ecosystem services by ecological restoration: a metaanalysis. Science, 325(5944), 1121-1124.

Carvalho, P. E. R. (1982). Comparação de espécies nativas, em plantio em linhas em capoeira, na região de IRATIPR - resultados aos sete anos. Boletim de Pesquisa Florestal, 5, 53-68.

Carvalho, P. E. R. (1994). Mimosa scabrella Bentham. var aspericarpa (Hoehne) Burkart. Espécies florestais brasileiras: recomendacoes silviculturais, potencialidades e uso da madeira. Colombo, 344- 347.

Carvalho, P. E. R (2002). Bracatinga. Embrapa Florestas-Circular Técnica (INFOTECA-E).

Chazdon, R. (2015). Restoring Tropical Forests: A Practical Guide. Ecological Restoration, 33, 118-119.

Costa, M. D. P., Pereira, J. A. A., Benicio, M. H. M., Sousa, H. D., Fontes, M. A. L., \& Garcia, P. O. (2012). Alometria e arquitetura de Copaifera langsdorffii (Desf.) Kuntze (Fabaceae) em fitofisionomias neotropicais no sul de minas gerais. Ciência Florestal, 22(2), 223-240.

Dutra, V. F., \& Morim, M. P. Lista de Espécies da Flora do Brasil. Jardim Botânico do Rio de Janeiro http://floradobrasil.jbrj.gov.br/jabot/floradobrasil/FB100978

Elliott, S., Blakesley, D., \& Hardwick, K. (2013). Restoring Tropical Forests: a practical guide. Royal Botanical Garden, Kew, $118-123$.

Fabrowski, F. J., Muñiz, G. I. B. D., Mazza, M. C. M., Nakashima, T.; Klock, U., Possamai, J. C., \& Nisgoski, S. (2005). Anatomia comparativa da madeira das variedades populares da bracatinga (Mimosa scabrella Bentham). Ciência Florestal, 15(1), 65-73.

Fontes, M. A. L. (1999). Padrões alométricos em espécies arbóreas pioneiras tropicais. Scientia Forestalis, 55 , 79-87.

Gerber, D., Topanotti, L. R., Gorenstein, M. R., Vieira, F. M. C., Stolarski, O. C., Nicoletti, M. F., \& Bechara, F. C. (2020). Performance of Guazuma ulmifolia Lam. in subtropical forest restoration. Scientia Forestalis, 48(127).

Guerin, N., \& Mendonça, A. H. Diferenças alométricas de Psidium cattleyanum Sabine em gradiente de restinga. São Lourenço: SEB, 1-3.

Klein, R. M. (1981). Aspectos fitofissociológicos da bracatinga (Mimosa scabrella Bentham. Colombo: EMBRAPACNPF.

Machado, S. A., Bartoszeck, A. C. P. S., Figueiredo Filho, A., \& Oliveira, E. B. (2006). Dinâmica da distribuição diamétrica de bracatingais na região metropolitana de Curitiba. Árvore, 30(5), 759-768.

Reis, A., Bechara, F. C., \& Tres, D. R. (2010). Nucleation in tropical ecological restoration. Scientia Agricola, 67(2), 244-250.

Reis, A.; \& Kageyama, P. Y. (2003). Restauração de áreas degradadas utilizando interações interespecíficas. Fepaf, 91-110.

Reitz, R., Klein, R., \& Reis, A. (1978). Projeto Madeira de Santa Catarina. Herbário Barbosa Rodrigues, 320p.

Ripple, W. J., Wolf, C., Newsome, T. M., Barnard, P., \& Moomaw, W. R. (2020). Corrigendum: World scientists' warning of a climate emergency. BioScience, 70(1), 8-12

Santos, M. C. N., Berg, E. V. D., Teodoro, G. S., Coelho, G. A. O., \& Fontes, M, A. L. (2012). Comportamento da copa e relações alométricas de três espécies arbóreas em corredores e bordas florestais. Revista brasileira de Biociências, 10(3), 322-326.

SAS Institute. (2004). The SAS System for Windows. Cary: SAS Institute.

Siqueira, A. S. (2006). Alometria de Caryocar brasiliense (Caryocaraceae) em diferentes fisionomias do Parque Estadual da Serra de Caldas Novas, GO. Biota Neotropica, 6, 1-6.

Souza, R. F., Machado, S. A., Figueiredo Filho, A., \& Koehler, H. S. (2013). Modelagem do carbono orgânico total e da lenha por unidade de área para bracatingais nativos. Ciência Florestal, 23(1), 117-127.

Steenbock, W., Siminski, A., Fantini, A. C., \& Reis, M. S. (2011). Ocorrência da bracatinga (Mimosa scabrella Benth.) em bracatingais manejados e em florestas secundárias na região do planalto catarinense. Árvore, 35(4), 845-857. 
Research, Society and Development, v. 10, n. 3, e33710312629, 2021

(CC BY 4.0) | ISSN 2525-3409 | DOI: http://dx.doi.org/10.33448/rsd-v10i3.12629

Sterck, F. J.; \& Bongers, F. (1998). Ontogenetic changes in size, allometry, and mechanical design of tropical rain forest tree. American Journal of Botany, 85, 266- 272 .

Terborch, J., \& Petren, K. (1991). Development of habitat structure through succession in an Amazonian floodplain forest. In: Bell S, Mccoy E, Mushinsky H. Habitat structure: the physical arrangement of objects in space. Chapman \& Hall, 28-46.

Wishnie, M. H., Dent, D. H., Mariscal, E., Deago, J., Cedeno, N.; Ibarra, D., \& Ashton, P. M. (2007). Initial performance and reforestation potential of 24 tropical tree species planted across a precipitation gradient in the Republic of Panama. Forest Ecology and Management, 243, 39-49. 